\title{
European Union: New Risks from the Actual Globalization
}

\author{
J. Adrian Ivorra, J. Manuel Bonilla, Francisco J. Brotons and Ángel Grediaga
}

Universidad de Alicante, Alicante, España

\begin{abstract}
This paper analyzes and explains different challenges the European Union (EU) is currently facing. It also analyzes the main impact that globalization has when trying to resolve these challenges.

The EU has identified several challenges that their understanding need to be resolved and settled during the 21st Century. Among these, but not limited to, are, unemployment, the integration of all European countries under the EU umbrella, and the multicultural and multiracial diversity so prevalent in the continent. If these challenges are tackled effectively, the EU will face and conquer, to a large extent, the main issues impacting all member nations. On the contrary, if the EU fails to resolve these challenges, the member nations will feel the consequences of increased unemployment and lack of political and social integration. Consequently, the up to now unattained main objective of a unified - politically and economically - Europe, will also fail.
\end{abstract}

The authors understand that globalization defines and determines the interaction of all different parts of our society. Therefore, it is a fair statement to emphasize that globalization is the context that frames all the conditions required to effectively face and resolve the challenges mentioned above.

Keywords: European Union, economic union, globalization, efficiency.

\section{Introduction}

Our objective is to analyze the present and future challenges to which the EU will have to react. In doing so, all challenges will be contextualized in the era of globalization. Given the amount and diversity of the challenges the EU is facing, here we will attain to explain a portion of those. To achieve this purpose, in this paper we will analyze globalization focusing on different dimensions together with the factors that are key players in each of these dimensions. We will also explain that, given the existing global problems in the worldsystem, the answers must be local.

\section{Globalization}

Technology and its developments have a strong social impact. Similarly, globalization has a strong social impact. Globalization is a multidimensional phenomenon that includes different processes operating at multiple scales (Ivorra, Grediaga, Brotons, \& Poves, 2010). The term itself refers to the expansion and intensification of social, cultural, military, political and economic relations. When we speak of globalization, it must be understood not only in an economic context but also in a political, cultural, military and social dimension.

Copyright (C) 2012 J. Adrian Ivorra, J. Manuel Bonilla, Francisco J. Brotons and Ángel Grediaga. This is an open access article distributed under the Creative Commons Attribution License unported 3.0, which permits unrestricted use, distribution, and reproduction in any medium, provided that original work is properly cited. Contact author: J. Adrian Ivorra E-maill: adrian.ivorra@ua.es 
Different players interact in each dimension of globalization (Rifkin, 1995). When discussing economic globalization we need to discuss international corporations such as IBM or McDonald's, or institutions like the International Monetary Fund (IMF) and the World Bank (WB). If we analyze the political globalization, we must discuss nation-states like Germany, USA or China, or institutions like the EU, the United Nations (UN) or the NonGovernmental Organization (NGO). Among the protagonists of cultural globalization, we find the UNESCO, brands like Coca Cola, Ikea or the great museums like El Prado, the Louvre or MOMA. When reviewing military globalization, NATO is the first international military organization that comes to mind. And in social, values such as equality, liberty, or habits, such as fever consumerist and norms such as respect for elders.

It is necessary that citizens understand what globalization is, what generates it, what effects arise from it and the potential it carries. Globalization can be defined in many ways, depending on what level you want to analyze it. We can discuss the globalization of the world, a country, a specific industry, a company, even a political and economic model. In its broadest definition, the term encompasses a process of increasing internationalization and globalization of the financial capital, of industries, the military, of commerce as a trade, political influence and well as social and cultural reach.

In this globalized world, not all the players are integrated in the same way to the global economy. Globalization is a dynamic and complex process that although not new, it has strongly emphasized the developing countries as a specific stage for greater economic growth.

\section{Global Issues and Local Implementation}

A global world requires a global response, but above all, it needs and requires a local action since the problem and the needs are local, i.e., problems and needs that are common throughout the world have specific impact in different areas or regions of the planet. In this paper we argue that we have to think locally and globally to implement local policy adequately. Therefore, the goal is the governance of globalization and the implementation at local level.

Here we also underline that there is an insufficient and inadequate response from the institutions, international agencies and state governments. We also emphasize that there is a lack of public awareness to global issues like global poverty particularly affecting certain and specific regions of the planet.

Along with this, we note that with the fall of communism and the voracity of capitalism, the new currents of thought pose a different and new contribution in this century. We insist on an organizational structure more complete, comprehensive and equal that overrides all previous ones, and creates a more just and appropriate platform to the level of social evolution in which we are immersed. All these aspects discussed so far determine the challenges that the EU should respond.

\section{Challenges}

\section{EU, Globalization and International Relations}

The first challenge before us is the position of the EU in the context of political globalization and its impact in the field of international relations. Among the main actors of political globalization are as mentioned, the nation-states and supranational institutions like the EU or the UN. At present, it is argued that the intensified globalization has diminished the powers of nation states. To this thesis there are two positions:

- The supporters say that the social and economic processes operate primarily at the global and regional, and national states have passed largely to be entities that implement other supra-national actors' decision.

- The opponents argue that the nation state, especially in advanced economies, is as robust and integrated as usual. 
It's clear that the EU and other regions of the world system are witnessing a transformation of the power of nation-state and a redefinition of its functions. States have a dual status in this global context. They are sovereign players and are also under severe restrictions by other supranational players. These issues call into question the conventional versions of a world order based on a nation-state, they also generate a much more complex situation in the EU and the regional and global order. As a result, the EU must balance this dialectical relationship that exists between the sovereignty of nation states and measures adopted within the EU.

\section{EU, Globalization and Politics}

We live in a society immersed in a world of immediacy, in the words of Anthony Giddens, we live in a "world flight" (Giddens, 1994). In a world of immediacy, politics and political parties coupled with the era of globalization, it must rediscover and defend their space because in Europe there is a growing public disaffection with politics and politicians.

The disappearance or absence of politics is creating an unprecedented crisis of governance specifically in the EU but also in many other regions of the world. We live, as we said, in a period of popular dissatisfaction with political institutions and hostility towards the task that, elected politicians and selected leaders, are hired to perform. In this regard, we question the appropriateness of the traditional channels of representation (parties / trade unions), to solve current problems. Similarly, the degree of alienation of a significant proportion of the population towards the political institutions has reached significant levels. This sense of alienation is growing in many countries. For example see the studies No.: 2,575 and No.: 2,588 made by the Sociological Research Centre of Spain.

European society demands a profound reflection of politicians and a redefinition of the role of political parties in order of preventing the rupture of the link between society, political parties and state. It is desirable that the EU and member states reconsider what role we expect political parties to play and what place we occupy in society; this would be a necessary and interesting communication between political parties and the New Social Movements. The EU must find ways of enhancing the participation of political representation; it is important to defend, and to know how to convey the importance of politics and the need for good policy in this society of immediacy (Enikolopov \& Zhuravskaya, 2007).

\section{EU, Globalization and Financial System}

During the last several years, we have come to realize that the financial systems have changed dramatically and that these changes are not predictable. We have also found that unpredictable changes in the financial system determine all other aspects of society. The financial system is vulnerable, creates turbulence and causes a domino effect on the systems; such turbulence and these ripple effects affect all systems and all economies.

The EU must be aware of these issues and learn from recent situations and the experience brought to the table by different regions and other key players of this global economy. Turbulence and the domino seem to be the new norm in the financial system.

For example, if we focus our study on nation-states and analyze key indicators to measure the integration of the economy of any given, we find that the exports and imports in terms of percentage of GDP, and FDI flow in financial markets that set and mark the differences. However, the EU should pay attention to this and other indicators, such as employment and consumer confidence in order to be able to better measure and predict the turbulence of the system.

\section{EU, Globalization and Ideology}

Different theories point to a depletion of ideological disputes between world views that claimed for themselves to have attained "the truth". Here we ask ourselves if the ideological struggle has been 
displaced by management. With the triumph of Western liberal democracy over its alleged alternatives - fascism and communism - we also wonder, has humanity reached the end of its ideological evolution? (Bell, 1960; Bobbio, 1994; Ostrogorski, 1979)

In the EU, the Social Democracy is in a clear ideological confusion. At the same time, the "right" is also struggling as a result of tensions between its two main components, (1) conservatism and (2) neoliberalism. The "Third Way" is drawn as a middle way between left and right with the combination of two fundamental values (1) freedom and (2) equality. We also wonder, is the "Third Way", the only possible and desirable political option at present?

As a response to these issues, we say that in a world where globalization is the backbone, the ideology is more necessary than ever and must not been displaced by the management, nor has humanity reached the end of ideological evolution. A better world is possible; the so-called "Third Way" is not the only political option possible.

In globalization, the boundaries are blurred and the markets show its peaks and lows, markets are an unstoppable force that do not understand limits and whose overriding premise is to achieve the highest possible performance. The left and right are still needed in the EU, and it is appropriate for this institution and the parties at the head of nation-states to adopt these ideologies and to reign in the firmness of the market while circumventing the inequality and social disruptions caused.

\section{EU, Globalization and Nationalism}

Nationalism is an ideological movement with a great capacity for mobilization. The nation-state, rational subjects and political players of the world system, together with the representatives democratically elected by the citizens, have raised different questions not easily solved. This dialectic and diatribe is currently happening in the EU.
Nationalism poses questions and challenges in the territorial map, in sovereign nation-states and also, it raises questions and challenges in the EU at the international relations field. With globalization, international relations are between supra-national institutions, between states, between nation-states, between multinationals corporations and organizations, and including also stateless nations, integrated economic regions within a given sovereign nation and lastly between integrated economic regions defending the concept of nationhood and statehood. This scenario is complex, dynamic, often exclusive, but always interesting for the any socio-economic and or simply a political study.

Before taxation, the EU must commit itself to cooperation and dialogue, through a dialectical process of integration of its different and specific cultures and nations and their respective nationalities and subsequently, integrating their idiosyncrasies. These are all different because they start and are characterized by dissimilar approaches yet specific, because they have proper characteristics.

\section{EU, Globalization and Multiculturalism}

Another challenge facing the EU is part of the field of multiculturalism. Specifically in the field of relations between different civilizations that inhabit the Earth. The EU has to base its international relations on respect for the diversity of ethnicities, races and cultures. It is clear that the contact and the flow of experience and knowledge among certain specific civilizations and cultures, have their origins in the beginning of humanity.

The different civilizations have different cultures and consequently different religious beliefs. Samuel Huntington argues that world politics is entering a new phase in which the fundamental source of conflict will be neither ideological nor economic, the great global division of humanity and the main source of conflict will be cultural (Huntington, 1993). 
The agenda of the EU must touch on the defense of the personality and human dignity while understanding, in a broad sense, the various civilizations that roam the Earth. One of the fundamental and growing facts in the post-industrial society is the inclusion, in different maps and territories, of individuals with different cultures and identities as well as different economic, political and social perspectives.

In the EU, the phenomenon of multiculturalism has a special significance and is of growing interest among citizens, between the political class and between the political and economic elite that governs (Blanco Valdés, 1996). The EU consists of countries, but also consists of a puzzle of different nationalities and identities. Multiculturalism is a complex and multidimensional phenomena. The main characteristic of multiculturalism is to comprehend the existence of a multiplicity of cultures. This principle argues that citizens retain their cultural identities and do not replace them but do enrich their own identity by learning from other identities in any given area. Giovanni Sartori defines multiculturalism as "a factual situation, i.e. an expression that simply records the existence of a multiplicity of cultures or defined as a value, and this is a priority (Sartori, 2000).

If the EU's objective is to achieve a multicultural society with respect and dialogue, the EU must keep in mind that cultures must be considered equivalent to each other in terms of their ability to interact with other cultures. The EU must find or create new functional organizations in both, the international and national levels, which exceed these limitations, and address the competing challenges of which we participate.

\section{EU, Globalization and Labor Market}

The EU has high rates of unemployment. For almost two decades we have witnessed significant changes in the economic and social fields (Rifkin, 1995). These changes affect the labor force and the labor needs which, on their own, are in an accelerated phase of transformation as a result of the previously explained, new normal of "turbulence" so prevailing in a global economy. In the design of employment policies, the EU should put the emphasis on collaboration between the social partners to further develop their great potential, take advantage of synergies, and achieve economies of scale (Wilpert, 2009).

The new employment reality requires competitiveness, training and efficiency. It also calls for more imagination on the part of public authorities, social partners, business communities and society as a whole. The EU must consider all these issues when evaluating the labor market. It is an already accepted fact that economic growth alone cannot restore a satisfactory situation in terms of job creation, and that the debate must turn on both the stability of the current job as well as the creation of new jobs and new policies. Needless to say, the EU also must take on these issues.

In short, the EU must consider and implement measures to enhance job creation in services related to people, while respecting the environment, promoting the recovery of the urban environment, enhancing training and re-training whenever needed and enabling workers to reconcile their personal and professional life. The EU must promote employment policies that meet the needs of a postindustrial society, and that know how to focus on public resources. The EU's strategy for growth and employment must be based on three pillars: sustainable growth, improving the potential for innovation and growth, and achieving a more active and greater social inclusion.

\section{EU, Globalization, Integration and Citizenship}

Since the gradual creation of the European Economic Community (EEC), to date, with the EU, the EU has had a clear challenge: to further deepen eastward enlargement in addition to promote the European feeling among citizens. To achieve this objective, the EU must pursue a teaching job and report the importance and benefits of being European citizens. 
The EU must internalize and disseminate a dynamic and permeable concept of European citizenship among its members. It must be dynamic to overcome the many vicissitudes inherent in the integration process, and must be permeable to the numerous peculiarities and idiosyncrasies of the people who make the EU. The EU must have a voice in the world and this voice must be representative of all European citizens. The challenge is clear.

\section{$E U$, Globalization and the United States of America}

An integrated and united EU, economically and politically, is only possible and feasible to increase the level of autonomy from the United States of America. There is an important premise in the context of international relationships, the United States does not want equal partners. In any bilateral or multilateral relationship, the United States of America is considered the strongest and better trained partner. This reaction has been evident in the recent Egyptian revolt, in the current Libyan turmoil.

The bilateral relation of countries in the EU with the United States, in some ways, weakens the strategic position of the EU in the world. While the bilateral relation of EU-US is necessary, the EU is responsible to make an effort to improve its strategic position in a global context and this effort must continually be reaffirmed by member states and their governments as a reflection of their policies and governance.

\section{EU, Globalization and World Leader in the XXI Century}

A final challenge for the $\mathrm{EU}$ is to assume the role of world leader in the XXI century, just as Britain assumed it in the XIX century and the United States in the XX century. To achieve this, the EU has to move forward on economic integration of member countries by promoting greater integration into the political arena. Therefore, economic union is a must, but it cannot happen without a stronger political union. To achieve this proposed global leadership, the EU would also have to move forward to integrate the rest of European countries in the EU.
The EU has a strong strategic position, an advanced economy, and over 501 million people (Corsini et al., 2010) which are provided with a good education (Lin \& Chiang, 2011). If these characteristics are enhanced by economic and political union, the EU can certainly achieve the leadership goal for the XXI century notwithstanding, nor underestimating the capacity and potential of the major challengers, the United States and China.

\section{Conclusions}

In this paper we have analyzed the present and future challenges to which the EU must respond. We are aware that they are not the only ones, there are many more challenges. We raised some of them and we have contextualized those within globalization. The EU must be a rational player who is aware of its weaknesses in order to overcome, and be cognizant of the threats it needs to avoid. The EU must also be very aware of its strengths and identify all the opportunities it has in order to excel. Here we have detailed the weaknesses and threats, but also we have described and explained the strengths and the opportunities it has. The game began several years ago, the EU has to keep playing.

\section{References}

Bell, D. (1960). 'The End of Ideology: On the Exhaustion of Political Ideas in the Fifties,'. Glencoe, IL, Free Press.

Blanco Valdés, R. L. (1996). "La Democracia y el Poder de los Partidos," Claves de Razón Práctica, 63, 24-33.

Bobbio, N. ( 1994). "Destra e Sinistra," Roma, Donzelli Editore.

Centro de Investigaciones Sociológicas (2004). 'Ciudadanía y Participación,' Estudio №: 2.575.

Centro de Investigaciones Sociológicas (2005). 'Representación y Participación Política en España,' Estudio №: 2.588.

Corsini, V., Gourdol, A., Kraszewska, K., Marcu, M., Oblak-Flander, A., Vasileva, K., et 
al. (2010). 'Main Demographic Trends,' In: Demography Report 2010. Eurostat, The Statistical Office of the European Union.

Enikolopov, R. \& Zhuravskaya, E. (2007). "Decentralization and Political Institutions," Journal of Public Economics, 91(11-12), 2261-2290.

Giddens, A. (1994). Beyond Left and Right: The Future of Radical Politics. Oxford: Polity Press.

Huntington, S. (1993). 'The Coming Clash of Civilizations,' In Theory and Society, 23, 7684.

Ivorra, A., Grediaga, Á., Brotons, F. J. \& Poves, J. A. (2010). 'The Technological Development: An Important Factor in the Social Change,' Proceedings of the 14th International Business Information Management Association, Istambul. Turkey.

Lin, W. T. \& Chiang, C.-Y. (2011). "The Impacts of Country Characteristics upon the Value of Information Technology as Measured by Productive Efficiency," International Journal of Production Economics, 132(1), 13-33.

Ostrogorski, M. (1979). 'La Démocratie et les Partis Politiques,' París, Du Seuil.

Rifkin, J. (1995). 'The End of Work. Decline of the Global Labor Force and the Dawn of the Post-Market Era,' New York Tarcher/Putnam.

Sartori, G. (2000). "Multiculturalismo Contra Pluralismo," Claves de Razón Práctica, 107, 4-8.

Wilpert, B. (2009). "Impact of Globalization on Human Work," Safety Science, 47(6), 727-732. 